\title{
Climate Change Impact on Water Availability and Demand of Irrigation Water - A Review
}

\author{
Kambale Janardan Bhima* \\ Department of Soil and Water Engineering, College of Agriculture, Bheemarayanagudi Tq: \\ Shahapur, Dist: Yadgir, Karnataka, India \\ *Corresponding author
}

\begin{tabular}{|l|}
\hline Ke y w o r d s \\
Crop/Irrigation Water \\
$\begin{array}{l}\text { Requirement, } \\
\text { Groundwater recharge, } \\
\text { Coping strategies }\end{array}$ \\
\hline Article Info \\
\hline $\begin{array}{l}\text { Accepted: } \\
\text { 25 March } 2018 \\
\text { Available Online: } \\
\text { 10 July 2018 }\end{array}$ \\
\hline
\end{tabular}

A B S T R A C T

In the present study, the review of the literature has been made to appraise the impact of climate change on crop water requirement, availability of irrigation water and suggested coping strategies. Most of the studies presented indicate that there is an increase in irrigation and crop water requirement. There are few studies which suggest that there may not be a change in crop water requirement in event of climate change. The studies also suggest that climate change would affect groundwater recharge and water availability for irrigation. The different studies revealed that the future will be tough for nations in the sensitive areas in particular whose irrigation water supplies are dependent on groundwater. To overcome the crisis of irrigation water shortage in the coming decades some coping strategies suggested by the various scientists are mostly generic in nature. Also, Effects of changes in climatic parameters which control the evapotranspiration have not been investigated in detail. In overall various studies shows the complex results based on the crop production and locations. Therefore, this initiates to review the climate change impacts on water availability and water demand for irrigation. This study will help to identify the gaps and scope for future research so that suitable adaptation and mitigation measures can be taken for water resources planning and management under climate change scenarios.

\section{Introduction}

Climate change and its impact on crop water requirement and availability of irrigation water are major concerns of this century. It has now been established that the global and regional climate is changing due to increased concentration of greenhouse gases (GHGs) in the atmosphere. The important climatic parameters which influence the crop water requirement and irrigation water availability are temperature, relative humidity, wind velocity, duration of sunshine hours, the amount of solar radiation reaching the earth surface, rainfall, rainfall intensity and its distribution pattern etc. It has been reported that due to the increased concentration of GHGs in the atmosphere, average surface temperature of the earth increased by $0.6^{\circ} \mathrm{C}$ in the twentieth century (MANN et al., 1998). There is enough evidence that atmospheric temperature is rising mainly because of GHG effects (MEHROTRA 1999; DOWNING et al., 2003). According to a study, the global 
mean surface temperature increased by $0.74^{\circ} \mathrm{C}$ $\pm 0.18^{\circ} \mathrm{C}$ during the period of 1906 to 2005 (TRENBERTH et al., 2007). Also, it is predicted that the global mean surface temperature would increase by 1.4 to $5.8^{\circ} \mathrm{C}$ by 2100 under different emission scenarios (IPCC 2007).

Several Governmental and Non-Governmental organisations in India have initiated studies on climate change and it impacts on agriculture and water resources (e.g., INCCA 2010). According to INCCA (2010), the annual mean surface air temperature of the Indian subcontinent is projected to rise by $1.7^{\circ} \mathrm{C}$ and $2.0^{\circ} \mathrm{C}$ in the $2030 \mathrm{~s}$. The INCCA has evaluated the impacts of climate variability in the four major climate sensitive regions of India, namely: the Himalayan region, the NorthEastern region, the Western Ghats and the Coastal region. Likely impacts of climate change in the 2030s on four key sectors namely; agriculture, water, natural ecosystems, biodiversity and human health were assessed (INCCA 2010).

Irrigated agriculture has played important role in increasing crop production and achieving food security in India. Groundwater has been an important source of irrigation in India. It has contributed immensely in increasing food production during green revolution. Its share in ultimate and utilized irrigation potential is $46 \%$ and $53 \%$, respectively. Net groundwater irrigated area in the country is $61 \%$ of total net irrigated area, which is much higher than the net irrigated area of $26 \%$ through canals (CWC 2010). The productivity of groundwater irrigated area is more than the canal irrigated area since it is available at point of use. However, due to over-exploitation and inefficient utilization, groundwater level in several regions of India is declining at a faster rate. In several regions in the country have turned into dark category (CGWB 2009). Groundwater recharge in these regions is not adequate to compensate the groundwater pumping. With expected change in climate and associated change in rainfall distribution pattern, groundwater recharge in arid and semi-arid regions may decline further. This will have a severe impact on agricultural production due to reduced availability of groundwater for irrigation. The main objective of this study was focused on groundwater irrigated area because groundwater is a major source of irrigation in India and the impact of climate change is expected to be more of groundwater recharge and its availability. Therefore, in this study, a critical review has been presented to know the impact of climate change on crop water requirement and water availability for irrigated agriculture.

\section{Irrigation and Crop Water requirement}

Crop water requirement mainly depends on the climate of the area. Any change in climatic conditions would definitely alter the water requirement of the crops grown in the area. The major climatic parameters which determine the crop water requirement are minimum and maximum temperature, rainfall, relative humidity; wind speed, evaporation, and the sunshine hours. It is well-established fact that the global temperature is rising due to the increase of GHGs in the atmosphere. In such circumstances, the water requirement is expected to increase in future. It is worth mentioning that evapotranspiration depends on other climatic parameters such as relative humidity, wind speed, and sunshine hours. Therefore, it is necessary to investigate the impact of climate change on crop water requirement considering expected changes in all climatic variables. There are several studies on impact of climate change on crop water requirement, which has been carried out in the different regions of the World (e.g. MAHMOOD 1997; DOLL 2002; DE SILVA 2007; ELGAALI 2007; NAGANO et al., 2007; YANO et al., 2007; DORIA and 
MADRAMOOTOO 2009; MIZYED 2009; ZIAD and SIREEN 2010; SHAHID 2011; CHOWDHURY et al., 2016) and in India (e.g. GOYAL 2004; ICAR 2009; CHATTERJEE $e t$ al., 2012; PAREKH and PRAJAPATI 2013).

\section{World}

MAHMOOD (1997) reported that 5\% increase and $4 \%$ decrease in total seasonal evapotranspiration under $1{ }^{\circ} \mathrm{C}$ warmer and $1{ }^{\circ} \mathrm{C}$ cooler air temperature conditions, respectively. DOLL (2002) reported that longterm average irrigation requirements might change around the world due to climate change. Further, Using ECHAM4 and HadCM3 climatic models, it was found that two-thirds of the global area would possibly suffer from increased water requirements. DE SILVA et al., (2007) derived climate change data sets for Sri Lanka using outputs from the HadCM 3 and predicted the impacts of climate change on paddy irrigation water requirement. It is reported that during the wet season, average rainfall decreased by $17 \%$ and $9 \%$ with rains ending earlier and potential evapotranspiration increased by $3.5 \%$ and $3 \%$, respectively. Due to this, the average paddy irrigation water requirement increased by $23 \%$ and $13 \%$, respectively. ELGAALI et al., (2007) reported an overall increase in irrigation water demands in Arkansas River Basin of southeastern Colorado due to climate change assuming no change in crop phenology. NAGANO et al., (2007) assessed impacts of climate change on the large irrigation district in Turkey with irrigation management performance assessment model and reported that irrigation demand and irrigation period would increase under the assumed climate change conditions. YANO et al., (2007) studied the effects of climate change on crop growth and irrigation water demand for wheat-maize cropping sequence in a Mediterranean environment of Turkey. It is reported that actual evapotranspiration for both wheat and maize decreased with a rise in temperature due to decreases in growing days and LAI. However, it predicted an increase in irrigation demand of wheat due to expected decrease in temperature. DORIA and MADRAMOOTOO (2009) assessed the impact of climate change on irrigation water requirement in Southern Quebec. It is reported that irrigation water requirement of potatoes and other vegetables would increase by $80 \%$ and $40-100 \%$, respectively during a dry year as compared to a normal year. The increase in temperature predicted by climate change might increase agricultural water demands by up to $17 \%$ in the West Bank (MIZYED 2009). ZIAD and SIREEN (2010) studied the impacts of climate change on agricultural water demand and reported that situation might be serious if a temperature rise of $3^{\circ} \mathrm{C}$ is accompanied by $20 \%$ decrease in precipitation levels. SHAHID (2011) reported that irrigation water requirement in North-west Bangladesh would increase by $0.8 \mathrm{~mm} /$ day due to climate change. CHOWDHURY et al., (2016) reported in Saudi Arabia in their studies on the implication of climate change on crop water requirement that because of $1^{\circ} \mathrm{C}$ rise in temperature crop water requirement may change by $2.9 \%$ in this region. Also, it is stated that the increase of crop water requirement is as a result of the mainly rising in temperature.

\section{India}

GOYAL (2004) studied the sensitivity of evapotranspiration to climatic parameters under global warming conditions. It is reported that $1 \%$ increase in temperature over base data could result in an increase in evapotranspiration by $15 \mathrm{~mm}$, which would mean an additional water requirement of 34.275 MCM for Jodhpur district alone and 313.12 MCM for the whole arid zone of Rajasthan. An increase of $14.8 \%$ in ET demand was reported with an increase in 
temperature by $20 \%$ (maximum $8^{\circ} \mathrm{C}$ ). Also, observed that ET was less sensitive to increase in net solar radiation which was followed by wind speed. The increase in vapor pressure exhibited a negative effect on ET. It is also reported that $10 \%$ increase in temperature and actual vapor pressure coupled with $10 \%$ decrease in net solar radiation resulted in a marginal decrease of total ET. ICAR (2009) reported that rise in temperature by $1^{\circ} \mathrm{C}$ by 2020 over the base year of 1990 is likely to increase the water requirement of major crops grown in Andhra Pradesh such as maize, groundnut, pigeon pea and cotton due to high evaporative demand. PAREKH and PRAJAPATI (2013) and CHATTERJEE et al., (2012) conducted the study at Sukhi Reservoir project and, Ganga River Basin, West Bengal in India, respectively to see the impact of climate change on crop water requirement using CROPWAT 8.0 model. The study revealed an increase in crop water requirement for Kharif and a negligible decrease in Rabi crops in future. Also, observed that requirement of irrigation water will increase by 7 to $8 \%$ in 2020 and 2050 it may increase by 14 to $15 \%$, respectively. Similar studies and their results for changes in Crop Water Requirement (CWR) and Irrigation Water Requirement (IWR) at different locations, crops and years are summarized in Table 1.

\section{Irrigation water availability}

Groundwater is one of the major sources of irrigation in India. It has played an important role in increasing agricultural production and food security in the country. The contribution of groundwater in ultimate irrigation potential of India is about $48.19 \%$ (CGWB 2009). The importance of groundwater can be realised by the facts that about $61 \%$ of net irrigated area irrigated by groundwater in the country (CWC 2010). However, large-scale development and utilisation in various parts of India have caused depletion of groundwater resources results in an increase of grey and dark areas in the country. In states like Delhi, Punjab, Haryana, Rajasthan, Uttar Pradesh, the stage of groundwater development in many blocks has reached over $100 \%$ implying that average annual groundwater extraction is more than the average annual groundwater recharge (CGWB 2009). With expected change in climate, it is anticipated that availability of groundwater resources will further be affected in several regions.

Recharge from the rainfall is a major source of groundwater. Groundwater recharge mainly depends on rainfall and its intensity, evapotranspiration, infiltration, soil moisture storage in the vadose zone, the hydraulic property of aquifer and depth of water table. Climate and groundwater recharge are closely related. Climate change is expected to influence groundwater recharge in several regions of the world including India. It is reported that there will be a major change in rainfall pattern due to climate change. High intensity and short duration rainfall events will become more common in future (IPCC 2007). Water resources would come under increasing pressure in Indian subcontinent due to the changing climate (MALL et al., 2004).

In a study conducted in Bangladesh, SHAHID (2011) found that there would be no appreciable changes in total irrigation water requirement due to climate change. However, there would be an increase in daily use for water for irrigation. A number of studies have been conducted to assess the impact of climate change on water resources and groundwater availability. The increase in temperature alone could reduce natural recharge of groundwater aquifers by $7 \%$ to $21 \%$ in the West Bank of Jordan Rift Valley (MIZYAED 2009). Reduction in fresh groundwater resources is reported in Central America, Mediterranean, South Asia, and South Africa under both high 
and low emission scenarios (RANJAN et al., 2006). It is reported that the strategic importance of groundwater for global water and food security will probably intensify under climate change due to the occurrence of more frequent and intense climate extremes (droughts and floods) besides, pronounced variability in precipitation, soil moisture and surface water (TAYLOR et al., 2012).

TAYLOR et al., (2013) analysed 55 year record of groundwater level observations in an aquifer of central Tanzania and observed the occurrence of episodic recharge resulting from high intense seasonal rainfall. It was also observed that such episodic recharge would interrupt multiannual recessions in groundwater levels and would maintain the water security of the groundwater dependent communities in this region. OLAGO et al., (2009) studied the impact of climate change on groundwater in the lake basins of Central Kenya Rift.

It was observed that the IPCC projected rainfall increase of $10-15 \%$ might not necessarily result in a proportional increase in groundwater recharge. LOÁICIGA et al., (2000) assessed the likely impacts of aquifer pumping on the water resources of the Edwards Balcones Fault Zone (EBFZ) aquifer, Texas in the United States and reported that the groundwater resources appeared to be threatened under $2 \times \mathrm{CO}_{2}$ climate scenarios under predicted growth and water demand. It was also revealed that without proper consideration to variations in aquifer recharge and sound pumping strategies, the water resources of the EBFZ aquifer could be severely impacted by a warmer climate. NYENJA and BATELAAN (2009) investigated the effects of climate change on groundwater recharge and base flow in the upper Ssezibwa catchment of Uganda and reported intensification in the hydrological cycle resulting in an increase in groundwater recharge from 20 to $100 \%$ from the prevailing recharge of $245 \mathrm{~mm} /$ year. The trend in increasing temperatures may reduce the net recharge in the Southern Manitoba, Canada (CHEN et al., 2004). The study on the impact of climate change on groundwater recharge and streamflow in Central European low mountain range revealed that climate change effects on mean annual groundwater recharge and streamflow would be small (ECKHARDT and ULBRICH 2003).

Climate has been considered as an important factor which controls groundwater recharge along with other factors such as soil, geology, vegetation and land use, topography and water table depth. As discussed earlier, one of the major impacts of the climate change is expected to be on irrigation water availability as it is highly dependent on climate and its interactions with hydrologic cycle.

Effect of climate change is expected to be more of groundwater availability. It is anticipated that imbalance in hydrologic in future would affect groundwater recharge and its availability, particularly in arid and semiarid regions. In India, majority of the irrigated area is under groundwater irrigation. Already, groundwater recharge in several regions of India has been affected due to declining water table, urbanization and other infrastructural developments (KAMBALE et al., 2009; NAYAK et al., 2016; KAMBALE et al., 2016).

The studies conducted so far also suggest that climate change would affect groundwater recharge water availability for irrigation. DIVYA and MEHROTRA (1995) studied the impact of climate change on hydrology for Indian Subcontinent. It is reported that water availability in reservoirs would be influenced by climate change. RANJAN et al., (2006) studied the effect of climate change on coastal fresh groundwater resources in Africa. 
Table.1 Changes in Crop Water Requirement (CWR) and Irrigation Water Requirement (IWR) at locations, crops and years

\begin{tabular}{|c|c|c|c|c|c|c|c|}
\hline $\begin{array}{l}\mathbf{S} \\
\mathbf{N}\end{array}$ & $\begin{array}{l}\text { Trend shows changes in } \\
\text { CWR/IWR }\end{array}$ & $\begin{array}{l}\text { Year of prediction/ } \\
\text { Scenario }\end{array}$ & $\begin{array}{l}\text { Base year/ } \\
\text { Scenario }\end{array}$ & Crops & Models used & $\begin{array}{l}\text { Region/ } \\
\text { Country }\end{array}$ & Reported by \\
\hline 1 & $\begin{array}{l}\text { Insignificant changes }(<2.5 \%) \\
7.1 \% \text { increase in } 1^{\mathrm{st}} \text { crop } \\
2.1 \% \text { decrease in } \mathrm{II}^{\mathrm{nd}} \text { crop }\end{array}$ & $2046-2065$ & 2004-11 & Paddy & GCM downscaled data & Taiwan & $\begin{array}{l}\text { LEE and } \\
\text { HUANG (2014) }\end{array}$ \\
\hline 2 & Increasing & A1B Scenario & $1969-2005$ & Paddy, Sugarcane, Citrus, Maize & GCM downscaled data & India & $\begin{array}{l}\text { REHANA and } \\
\text { MUJUMDAR } \\
(2012)\end{array}$ \\
\hline 4 & $\begin{array}{l}\text { Increasing (Kharif), negligible } \\
\text { decreasing (Rabi) }\end{array}$ & $\begin{array}{l}2021-30,2046-65 \\
\text { and } 2080-99\end{array}$ & 2003-09 & $\begin{array}{l}\text { Kharif crops-Millet. Groundnut, } \\
\text { maize, tomato and other vegetables } \\
\text { Rabi crops- } \\
\text { Sorghum, Maize, Tomato, and } \\
\text { other vegetables }\end{array}$ & $\begin{array}{l}\text { HadCM3 and } \\
\text { CROPWAT-8.0 }\end{array}$ & India & $\begin{array}{l}\text { PAREKH and } \\
\text { PRAJAPATI } \\
(2013)\end{array}$ \\
\hline 5 & $5 \%$ increase & A1B Scenario & 2010 & Overall & $\begin{array}{l}\text { GCM downscaled data } \\
\text { and CROPWAT- } 8.0\end{array}$ & India & $\begin{array}{l}\text { MOHAN } \\
\text { RAMSUNDRAM } \\
(2014)\end{array}$ \\
\hline 6 & Decrease (4 mm/decade) & $\begin{array}{l}\text { Past } 59 \text { years } \\
(1955-2013)\end{array}$ & - & Winter wheat & - & China & $\begin{array}{l}\text { HUANG et al., } \\
(2016)\end{array}$ \\
\hline 7 & $\begin{array}{l}2.9 \% \text { increase for } 1^{0} \mathrm{C} \\
\text { Temperature rise }\end{array}$ & $2011-2015$ & 2009 & $\begin{array}{l}\text { Wheat, Maize, Barley, Tomato, } \\
\text { Potato, Dates, Citrus and Grapes }\end{array}$ & CROPWAT-8.0 & $\begin{array}{l}\text { Saudi } \\
\text { Arabia }\end{array}$ & $\begin{array}{l}\text { CHOWDHARY } \\
\text { et al., (2016) }\end{array}$ \\
\hline 8 & $\begin{array}{l}40 \% \text { increase in annual } \\
\text { volume of water }\end{array}$ & 2030 & - & Overall & $\begin{array}{l}\text { GCM downscaled data } \\
\text { and Monte Carlo } \\
\text { Simulator }\end{array}$ & Kenya & $\begin{array}{l}\text { MAEDA et al., } \\
(2011)\end{array}$ \\
\hline 9 & $13 \%$ decrease in water flows & $2036-65$ & $1976-2005$ & Overall & - & Nigeria & $\begin{array}{l}\text { SANTINI } \text { et al., } \\
(2013)\end{array}$ \\
\hline 10 & Increasing & - & - & Overall & $\begin{array}{l}\text { Daily Water Budget } \\
\text { model }\end{array}$ & Chile & $\begin{array}{l}\text { MEZA at al. } \\
(2012)\end{array}$ \\
\hline 11 & $37 \%$ increase & 2070-99 & $1961-1990$ & Overall & $\begin{array}{l}\text { GCM downscaled data } \\
\text { and PRISM }\end{array}$ & Canada & $\begin{array}{l}\text { NEILSEN at al. } \\
(2004)\end{array}$ \\
\hline 12 & $7-8 \%$ and $14-15 \%$ respectively & $\begin{array}{l}2020 \text { and } 2050 \\
\text { respectively }\end{array}$ & 2010 & Potato & $\begin{array}{l}\text { PRECIS output and } \\
\text { CROPWAT- } 8.0\end{array}$ & India & $\begin{array}{l}\text { CHATTERJEE } \text { et } \\
\text { al., (2012) }\end{array}$ \\
\hline 13 & Insignificant changes & $\begin{array}{l}\text { IPCC Scenarios for } \\
2020 \text { s } 2050 \text { s and } \\
2080 \text { s }\end{array}$ & $\begin{array}{l}1973-2000,1971- \\
2000 \text { and } 1986- \\
2000\end{array}$ & Rice-Wheat & $\begin{array}{l}\text { HadCM3, CROPWAT } \\
8.0\end{array}$ & Nepal & $\begin{array}{l}\text { SHRESHTHA et } \\
\text { al., (2013) }\end{array}$ \\
\hline
\end{tabular}


Among the five selected water resources stressed areas, both high and low emission scenarios had more impacts on fresh groundwater resources suggesting the complexity of hydrological consequences. Also, reported a reduction in fresh groundwater resources in all studied regions except the northern Africa/Sahara region under for both high and low emission scenarios. GOKHALE and SOHONI (2015) developed a quantitative groundwater assessment protocol to use the data available at different scales with government agencies in Maharashtra State to predict the groundwater level fluctuations under varying rainfall depths.

It was reported that there existed an uncertainty in the prediction of groundwater table depth both within and across years and rainfall alone was a poor predictor of groundwater depths. It was suggested to consider the land use and irrigation requirement besides the hydro-climatic parameters while predicting the groundwater table fluctuations at regional scales.

FICKLIN et al., (2010) used the Hydrus-1D model to assess the impact of climate change on groundwater recharge from the field under different crops in the San Joaquin watershed in California. It was reported that that increase in the daily temperature by $1.1^{\circ} \mathrm{C}$ and $6.4^{\circ} \mathrm{C}$ would decrease the cumulative groundwater recharge. LETERME and MALLANTS (2011) simulated the climate change impact on groundwater recharge using HYDRUS-1D and reported a decrease in groundwater recharge in Dessel of NorthEastern Belgium under a warmer climate. Over the last several years, many researchers have initiated work on assessment of impacts of climate change on groundwater resources (WESSOLEK and ASSENG 2006; SCIBEK et al., 2007; PINGALE et al., 2014). Therefore, above discussion clearly shows the impact of climate change on groundwater recharge and its availability in future.

\section{Coping strategies to climate change for irrigated crops}

Climate change and its impact been recognized as the hottest topic in this century. Millions of dollars are being spent to study the impact of climate change and to develop mitigation, adaptation and coping strategies to overcome the impact of climate change. Increase in irrigation source capacity, an increase in irrigation efficiency, development of drought tolerant varieties and change in cropping pattern are some of the recommendation for coping with climate change impacts on water resources and agriculture (IPCC 2001). The increase in surface and sub-surface water storages are potential options to maintain water supply during prolonged dry spells. With increasing concerns about climate change and its impacts on agriculture, research is being carried out throughout the world to develop coping strategies.

TUNG and HAITH (1998) studied the climate change impact on irrigated maize and found the adverse impacts of climate change can be significantly minimized by irrigation and the right choice of cultivars and planting dates. MIZYED (2009) suggested as potential strategies to manage the impact of climate change are the construction of soil and water conservation, use of efficient irrigation systems, cultivation under controlled environment, water harvesting and artificial groundwater recharge. UNFCC (2007) compiled the adaptation measures received by under national communications of developing countries. According to it erosion control, dam construction for irrigation, changes in planning and harvesting times, switch to different cultivars, educational and outreach programs on conservation and management of 
soil and water are potential adaptation measures to mitigate the impact of climate change on agriculture and food security. It has also suggested strategies such as protection of groundwater resources, improved management and protection of existing water supply system, protection of water catchment areas, improved water supply and groundwater and rainwater harvesting and desalination mitigate the impact of climate change on water resources (KAMBALE et $a l ., 2015)$. UNFCC also highlighted the use of traditional practices such as intercropping, mixed cropping, agroforestry, terracing, surface water and groundwater irrigation; and diversification in agriculture terracing to cope with local climate change (UNFCC, 2007).

According to TRIPATHI and SHARDA (2011), the size of field bund in medium soil is expected to increase by $33.3 \%, 71.1 \%$ and $113.3 \%$ with an increase in one day maximum rainfall by $20 \%, 40 \%$ and $60 \%$, respectively, more than the cross section in relation to the one day maximum rainfall for the base of 1961-1990. It was also reported that the cross section of the field bunds in light textured soil would have to be increased by $30.9 \%, 65.5 \%$ and $103.6 \%$ for the same increase in one day maximum rainfall. It was also projected that the earthwork for bunding would increase by $17 \%$ if one day maximum rainfall increases by $20 \%$. These can be considered as major impacts of climate change on water resources development and conservation. The strategies suggested to cope with the climate change impacts are mostly generic in nature. In India and other regions of the world, these are normally not based on consideration of the impact of climate change on agriculture.

In the present review paper, an effort has been made to forward the changes related to climate change (an unpretentious increase in atmospheric temperature and other metrological parameters) will be responsible for changes in the availability of irrigation water. The model/predicted changes in some places are already being seen in the observed data. If it persists at current levels, these changes will lead to a serious reduction in irrigation water availability in many countries/regions of the Earth within the next few decades. The review also reveals that the future will be tough for nations in the sensitive areas, particularly whose irrigation water supplies are dependent on groundwater. This study will help the researchers and scientists to focus on research related to irrigation water availability, groundwater and climate change. Hence, the different efforts can be made towards the achievement of food security in the different regions of the world in alarming effects of climate change.

\section{References}

CGWB (2009) Groundwater scenario of India 2009-10. Ministry of Water Resources, Government of India. Faridabad: 1-46.

Chatterjee S.K., Banerjee S., Bose M. 2012. Climate change impact on crop water requirement in Ganga River Basin, West Bengal, India. 3rd International Conference on Biology, Environment and Chemistry Singapore, 46:17-20.

Chattopadhay N., and Hulme M. (1997) Evaporation and potential evapotranspiration in India under conditions of recent and future climate change, Agricultural Forest Meteorology. Vol. 87 No. 1, pp. 55-72.

Chaudhary T.N., Bhatanagar V.K., Prihar S.S. 1975. Corn yield and nutrient uptake as affected by water table depth and soil submergence. Agronomy Journal. Vol. 67, pp.745-749.

Chen Z. 2004. Relation between climate variability and groundwater levels in the upper carbonate aquifer, Southern Manitoba, Canada. Journal of Hydrology. Vol. 290, No. (1-2), pp. 43-62.

Chowdhury S., Al-Zahrani M., Abbas A. 2016. Implications of climate change on crop 
water requirements in arid region: An example of Al-Jouf, Saudi Arabia. Journal of King Saud University Engineering Sciences. Vol. 28, pp. 21-31.

CWC 2010. Water and related statistics. Information system organization Water planning \& project wing, Central Water Commission: pp.1-264.

De Silva C.S., Weatherhead E.K., Knox J.W. 2007. Predicting the impacts of climate change-a case study on paddy irrigation water requirements in Sri Lanka. Agricultural Water Management. Vol.93, No.12, pp.19-29.

Diersch H.J. 2005 FEFLOW reference manual. Berlin: WASY GmbH Institute for Water Resources Planning and Systems Research.

Divya Mehrotra R. 1995 Climate change and hydrology with emphasis on the Indian subcontinent. Hydrological sciences Journal. Vol.40, No.2, pp.231-242.

Doll P. 2002 Impact of climate change and variability on irrigation requirements: a global perspective. Climatic Change Vol.54, pp.269-293.

Doorenbos J., and Pruitt W.O. 1984. Guidelines for predicting crop water requirements. Irrigation and drainage paper 24. Food and Agriculture Organization (FAO), United Nations, Rome.

Doria R.O., and Madramootoo C.A. 2009. Estimation of irrigation requirements for some crops in southern Quebec using CROPWAT. Irrigation and Drainage. doi:10.1002/ird.497

Downing T., Butterfield B., Edmonds D., Knox W., Moss S., Piper B., Weatherhead E.K. 2003. CCDeW: climate change and demand for water revisited. Final research report to DEFRA. Stockholm Environment Institute Oxford Office, UK. Droogers P. 2004. Adaptation to climate change to enhance food security and preserve environmental quality: example for southern Sri Lanka. Agricultural water Management. Vol.66, pp.15-33.

Durand W. 2005. Assessing the impact of climate change on crop water use in
South Africa. Report submitted to World Bank. Centre for Environmental Economics and Policy in Africa (CEEPA) of the University of Pretoria.

Dutta D., Das D.K. 2001. Water requirement of some crops grown under shallow perched water-table at Indira Gandhi Canal command, western Rajasthan. Journal of the Indian Society of Soil Science. Vol.49, pp.1-6.

Eckhardt K., Ulbrich U. 2003. Potential impacts of climate change on groundwater recharge and streamflow in a central European low mountain range. Journal of Hydrology Vol. 284, pp. 244-252.

Elgaali E., Garcia L.A., Ojima D.S. 2007. High resolution modeling of the regional impacts of climate change on irrigation water demand. Climatic Change. Vol.84, pp.441-461.

FAO 1998. Guidelines for computing crop water requirements. Irrigation and Drainage paper. No.56. FAO, Rome.

FAO 2009. CROPWAT - a computer program for irrigation planning and management. FAO Irrigation and Drainage paper No.56. Food and Agriculture Organization, Rome.

Feddes R., De Rooij G., Van Dam J. 2004. Unsaturated zone modelling: progress, challenges and applications. Kluwer, Dordrecht.

Feddes R., Kowalik P., Zaradny H. 1978. Simulation of field water use and crop yield. John Wiley and Sons, NY.

Feddes R.A., Bresler E., Neuman S.P. 1974. Field test for a modified numerical model for water uptake by root systems. Water Resources Research. Vol.10, pp.11991206.

Ficklin D.L., Elike L., Zhang M. 2010. Sensitivity of groundwater recharge under irrigated agriculture to changes in climate, $\mathrm{CO}_{2}$ concentrations and canopy structure. Agricultural Water Management. Vol.97, pp.1039-1050.

Gokhale R., Sohoni M. 2015. Data-driven behavioural characterization of dryseason groundwater-level variation in 
Maharashtra, India. Journal of Earth System Science. Vol.124, pp.767-781.

Gosain A.K., Rao S., Basuray D. 2006. Climate change impact assesment on hydrology of Indian river basins. Current Science. Vol. 90, pp. 346-353.

Goyal R.K. 2004. Sensitivity of evapotranspiration to global warming: A case study of arid zone of Rajasthan (India). Agriculture Water Management. Vol. 69, No. 1, pp.1-11.

Huang H, Han Y, Song J, Zhang Z, Xiao H. 2016. Impacts of climate change on water requirements of winter wheat over 59 years in the Huang-Huai-Hai Plain. Soil and Water Res. Vol.11, pp.11-19.

ICAR 2009. Climate change, DARE/ICAR Annual Report, 2008-2009, pp.16.

INCCA 2010. Indian Network for Climate Change Assessment, Climate Change and India: A 4x4 Assessment, Ministry of Environment and Forests, Government of India.

IPCC 2001. Special report on emission scenarios. Cambridge University Press, pp.61.

IPCC 2007. Climate change 2007: The physical science basis. Contribution of working group I to the fourth assessment report of the Intergovernmental Panel on Climate Change. Cambridge University Press, Cambridge, United Kingdom an New York, NY, USA.

Kambale J. B, Singh, D. K. Sarangi A. 2017. Impact of climate change on groundwater recharge in a semi-arid region of northern India. Applied Ecology and Environmental Research, 15(1): 335-362.

Kambale J.B., Singh D.K., Sarangi A. 2015. Strategies for climate change impacts on irrigated crops in National Capital Region of India. Journal of Applied and Natural Science. Vol.7, No.1, pp.388-393.

Keese K.E., Scanlon B.R., Reedy R.C. 2005. Assessing controls on diffuse groundwater recharge using unsaturated flow modeling. Water Resources Research 41:W06010, doi: doi:10.1029/2004WR003481.
Leslie A., Donald D.A., Walter J., Eggleston R., Mark T.N. 2002. Simulation of groundwater flow and evaluation of watermanagement alternatives in the upper Charles river basin, Eastern Massachusetts. Water-Resources Investigations Report 02-4234. Northborough, Massachusetts.

Leterme B., Mallants D. 2011. Climate and land use change impacts on groundwater recharge. Proceedings Model CARE 2011 held at Leipzig, Germany, in September 2011) (IAHS Publ. 3XX, 201X).

Loáiciga H.A., Maidment D.R., Valdes J.B. 2000. Climate-change impacts in a regional karst aquifer, Texas, USA. Journal of Hydrology. Vol.227, No.1-4, pp.173-194.

Maeda E.E., Pellikka P.K.E., Clark B.J.F., Siljander M. 2011. Prospective changes in irrigation water requirements caused by agricultural expansion and climate changes in the eastern arc mountains of Kenya. J Environ Manage. Vol. 92, pp.982-993.

Mahmood R. 1997. Impacts of air temperature variations on the Boro rice phenology in Bangladesh: implications for irrigation requirements. Agricultural Forest Meteorology. Vol.84, No. 3-4, pp.233247.

Mali S.S. 2004. Studies on groundwater recharge processes and potential. M.Sc. Thesis. Division of Agricultural Engineering, IARI, New Delhi-12.

Mane M.S., Singh D.K., Singh A.K., Bhattacharya A.K. 2007. Development of GIS interface Con2grid for groundwater model. Current Science. Vol.92, No. 9, pp.1297-1302.

Mann M.E. 1998. On smoothing potentially non-stationary climate time series. Geophysical Research Letter Vol. 31:L07214.

Mehrotra R. 1999. Sensitivity of runoff, soil moisture and reservoir design to climate change in central Indian rivers basin. Climatic Change. Vol.42, pp.725-757. 
Meza F., Wilks D., Gurovich L., Bambach N. 2012. Impacts of Climate Change on Irrigated Agriculture in the Maipo Basin, Chile: Reliability of Water Rights and Changes in the Demand for Irrigation. J Water Resour Plann Manage Vol.138, pp. 421-430.

Mizyed N. 2009. Impact of climate change on water resources availability and agricultural water demand in the west bank. Water Resources Management Vo.23, No.10, pp.2015-2029.

Mohan S., Ramsundram N. 2014. Climate Change and its Impact on Irrigation Water Requirements on Temporal Scale. Irrigat Drainage Sys Eng Vol.3:118. doi:10.4172/2168-9768.1000118.

Nagano T., Hoshikawa K., Donma S., Kume T., Önder S., Özekici B., Kanber R., Watanabe T. 2007. Assessing impact of climate change on the large irrigation district in turkey with irrigation management performance assessment model. International congress on river basin management. pp. 651-664.

Nayak A.K., Sahoo S, Jha M.K., Pingale S.M. 2016. Hydrologic and hydrogeologic analyses of an alluvial aquifer underlying Kushabhadra-Bhargavi River Basin, Odisha, India. Arabian Journal of Geoscience, Springer. Vol.9, No. 15: doi:10.1007/s12517-016-2690-5 (In press).

Neilsen D., Smith CAS, Frank G., Koch W.O., Parchomchuk P. 2004. Impact of climate change on crop water demand in the Okanagan valley, B.C., Canada. Acta Hortic Vol.638, pp.273-278.

Nyenje P.M., Batelaan O. 2009. Estimating the effects of climate change on groundwater recharge and base flow in the upper Ssezibwa catchment, Uganda. Hydrological Sciences Journal Vol.54, No.4, pp.713-726.

Olago D., Opere A., Barongo J. 2009. Holocene palaeohydrology, groundwater and climate change in the lake basins of the Central Kenya Rift. Hydrological
Sciences Journal Vol.54, No.4, pp.765780.

Parekh F., Prajapati A.P. 2013. Climate change impacts on crop water requirement for Sukhi Reservoir project. International Journal of Innovative Research in Science, Engineering and Technology. Vol.2, No.9, pp.4685-4692.

Pingale S.M, Jat M.K., Khare D. 2013. Integrated urban water management modelling under climate change scenarios. Resour Conserv Recycl. Vol.83, pp.176-189.

Post D.A., Moran R.J. 2013. Provision of usable projections of future water availability for southeastern Australia: The South Eastern Australian Climate Initiative. Australian Journal of Water Resources Vol.17, No.2, 135-142.

Ranjan P.S., Kazama S.O., Sawamoto M. 2006. Effects of climate and land use changes on groundwater resources in aquifers. Journal of Environmental Management Vol.80, pp.25-35.

Ravi R., Ballukraya P.N., Thangarajan M. 2001. Mathematical modelling of Chennai area aquifer system. Modelling in Hydrogeology, Eds: UNESCO-IHP, Allied Publishers, pp.81-91.

Rehana S., Mujumdar P.P. 2013. Regional impacts of climate change on irrigation water demands. Hydrol Process Vol.27, pp.2918-2933.

Rosenzweig C., Parry M.L. 1994. Potential impact of climate change on world food supply. Nature Vol.367, pp.133-138.

Santini M, Valentini R, Cervigni R 2013. Climate projection ensemble as support to water management and irrigation in Nigeria. J Water Clim Change. Vol.4, pp.287-301.

Scanlon B.R., Healy R.W., Cook P.G. 2002. Choosing appropriate techniques for quantifying groundwater recharge. Hydrogeology Journal Vol.10, pp.18-39.

Scibek J., Allen D., Cannon A., Whitfield P. 2007. Groundwater-surface water interaction under scenarios of climate change using a high-resolution transient 
groundwater model. Journal of Hydrology Vol.333, pp.165-181.

Shahid S. 2011. Impact of climate change on irrigation water demand of dry season Boro rice in northwest Bangladesh. Climatic change 105:433-453.

Shrestha S., Gyawali B., Bhattarai U. 2013. Impacts of climate change on irrigation water requirements for rice-wheat cultivation in Bagmati River Basin, Nepal. Journal of Water and Climate Change Vol.4, No.4, pp. 422-439.

Taylor R.G. et al., 2012. Evidence of the dependence of groundwater resources on extreme rainfall in East Africa. Nature Climate Change Vol.1731, pp.1-8.

Taylor R.G. et al., 2013. Ground water and climate change. Nature Climate Change Vol.3, pp.322-329.

Trenberth K., Stepaniak D.P., Caron J.N. 2007. Atlantic hurricanes and natural variability in 2005. Geophysical Research Letter 33:L12704.

Tung CP, Haith DA (1998) Climate change, irrigation and crop response. Journal of the American Water Resources Association Vol.24, No.5, pp.1071-1085.

Twarakavi N.K.C., Simunek J., SEO S. 2008. Evaluating interactions between groundwater and Vadose zone using the
HYDRUS- Based flow package for MODFLOW. Vadose Zone Journal. Vol.7, pp.757-768.

UNFCCC 2007. Vulnerability and adaptation to climate change in Small Island developing States - Background paper for the expert meeting on adaptation for Small Island developing States. UNFCCC Secretariat. Bonn, Germany.

Ward S. 2002. Recharge and groundwater models: An overview. Hydrogeology Journal Vol.10, pp.110-120.

Wessolek G., Asseng S. 2006. Trade-off between wheat yield and drainage under current and climate change conditions in northeast Germany. European Journal of Agronomy Vol.24, pp.333-342.

Yano T., Aydin M., Haraguchi T. 2007. Impact of climate change on irrigation demand and crop growth in a Mediterranean environment of Turkey. Sensors Vol.7, pp.2297-2315.

Ziad A.M., Sireen A.J. 2010. Climate change and agricultural water demand: Impacts and adaptations. African Journal of Environmental Science and Technology. Vol.4, No.4, pp.183-191.

\section{How to cite this article:}

Kambale Janardan Bhima. 2018. Climate Change Impact on Water Availability and Demand of Irrigation Water - A Review. Int.J.Curr.Microbiol.App.Sci. 7(07): 4349-4360. doi: https://doi.org/10.20546/ijcmas.2018.707.507 